CURRENT RESEARCH JOURNAL OF PHILOLOGICAL SCIENCES

(ISSN -2767-3758)

VOLUME 03 ISSUE 01 Pages: 127-131

SJIF IMPACT FACTOR (2021: 5. 823)

OCLC - 1242423883 METADATA IF - 6.925

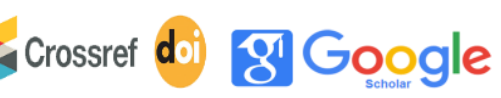

10.

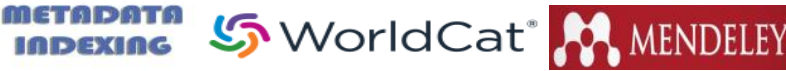

Publisher: Master Journals

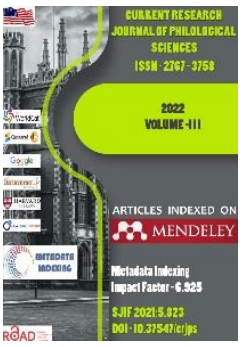

Journal Website: https://masterjournals. com/index.php/crips

Copyright: Original content from this work may be used under the terms of the creative commons attributes 4.0 licence.
Research Article

\section{DIFFICULTIES OF PHRASEOLOGY IN ENGLISH LINGUISTICS}

Submission Date: January 09, 2022, Accepted Date: January 21, 2022,

Published Date: January 31, 2022

Crossref doi: https://doi.org/10.37547/philological-crips-03-01-22

Nargiza Amirkulova

Senior Lecturer of Karshi State University, Uzbekistan

\title{
ABSTRACT
}

The phraseology is identified also by the collection of the firm combinations in the language as a whole, in the language of this or that writer, in the language of separate artistic work, etc. This article provides an overview of the problems of phraseology in English linguistics.

\section{KEYWORDS}

Phraseology, linguistics, phraseologisms, phraseological units, word groups, combinations in the language.

\section{INTRODUCTION}

Phraseology (Greek. phrasis - "expression", logos "teaching") - a section of linguistics, deals with firm combinations in a language. The phraseology is identified also by the collection of the firm combinations in the language as a whole, in the language of this or that writer, in the language of separate artistic work, etc. As an independent linguistical discipline phraseology appeared relatively recently. Subject and tasks, volume and methods of its study are not enough clearly researched and have not investigated completely. The questions about the main particularity of phraseologisms in contrast with free word-combinations, about categorizations of the phraseological units and correlation them with parts of speech and others are not clearly worked out. 
CURRENT RESEARCH JOURNAL OF PHILOLOGICAL SCIENCES

(ISSN -2767-3758)

VOLUME 03 ISSUE 01 Pages: 127-131

SJIF IMPACT FACTOR (2021: 5. 823)

OCLC - 1242423883 METADATA IF - 6.925

Crossref
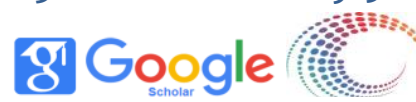

metapenta

5. WorldCat ${ }^{\circ}$ f̂े MENDELEY

Publisher: Master Journals

\section{MATERIALS AND METHODS}

There is even no unique determination of phraseologisms. A group of researchers (L. P. Smith, V. P. Jukov, V. N. Teliya, N. M. Shanskiy and others) comprise in phraseological units' composition their firm combinations, while others (N. N. Amosova, A. M. Babkin, A. I. Smirnitskiy and others) include only certain groups. So, some linguists (including academician V.V. Vinogradov) do not include into the category of phraseologisms such things like proverbs, sayings and popular expressions, considering that they differ by their semantics and syntax structure from phraseological units. V.V. Vinogradov confirmed: "Proverbs and sayings have a structure of the sentence and are not a semantic equivalent of words". The task of phraseology as a linguistical discipline includes the all-round study of the phraseological fund of this or that language.

The important aspect of the study of this science is: stability of the phraseological units, systematicality of phraseology and semantic structure of phraseological units, their origin and main functions. Particularly complex branch to phraseology is a translation of phraseological units, requiring considerable experience in the sphere of study of this discipline [1].

Phraseological units, or idioms, as they are called by most western scholars, represent what can probably be described as the most picturesque, colourful and expressive part of the language's vocabulary.

If synonyms can be figuratively referred to as the tints and colours of the vocabulary, then phraseology is a kind of picture gallery in which are collected vivid and amusing sketches of the nation's customs, traditions and prejudices, recollections of its past history, scraps of folk songs and fairy-tales. Quotations from great poets are preserved here alongside the dubious pearls of philistine wisdom and crude slang witticisms, for phraseology is not only the most colourful but probably the most democratic area of vocabulary and draws its resources mostly from the very depths of popular speech.

The metaphor fancy-dress ball may seem far-fetched to skeptical minds, and yet it aptly reflects a very important feature of the linguistic phenomenon under discussion: most participants of the carnival, if we accept the metaphor, wear masks, are disguised as something or somebody else, or, dropping metaphors, word-groups known as phraseological units or idioms are characterised by a double sense: the current meanings of constituent words build up a certain picture, but the actual meaning of the whole unit has little or nothing to do with that picture, in itself creating an entirely new image.

So, a dark horse mentioned above is actually not a horse but a person about whom no one knows anything definite, and so one is not sure what can be expected from him. The imagery of a bull in a china shop lies very much on the surface: the idiom describes a clumsy person (cf. with the R. слон в посудной лавке). A white elephant, however, is not even a person but a valuable object which involves great expense or trouble for its owner, out of all proportion to its usefulness or value, and which is also difficult to dispose of. The green-eyed monster is jealousy, the image being drawn from Othello. To let the cat out of the bag has actually nothing to do with cats, but means simply "to let some secret become known". In to bark up the wrong tree (Amer.), the current meanings of the constituents create a vivid and amusing picture of a foolish dog sitting under a tree and barking at it while the cat or the squirrel has long since escaped. But the actual meaning of the idiom is "to follow a false scent; to look for somebody or something in a wrong place; 
CURRENT RESEARCH JOURNAL OF PHILOLOGICAL SCIENCES

(ISSN -2767-3758)

VOLUME 03 ISSUE 01 Pages: 127-131

SJIF IMPACT FACTOR (2021: 5. 823)

OCLC - 1242423883 METADATA IF - 6.925

to expect from somebody what he is unlikely to do". The idiom is not infrequently used in detective stories: The police are barking up the wrong tree as usual (i.e. they suspect somebody who has nothing to do with the crime) [2].

The ambiguousness of these interesting word groups may lead to an amusing misunderstanding, especially for children who are apt to accept words at their face value.

The phraseology develops the principles of the separation of phraseological units, methods of their study, categorizations and phraseography descriptions in dictionary. The phraseology uses different methods of study, for instance componential analysis of meaning. On the basis of existing linguistic methods of study phraseological ways of analysis and descriptions":

1. Method of identifications - a determination of identical words and syntax structure, forming phraseologisms, with their free analogues;

2. Method of application, which is the variety of identification method, the method limited in choice of variables, establishing excellent structured-semantic organizations of phraseologisms from combinations formed in accordance with regular rules of the choice and combinations, etc. The phraseology offers different types of a classification of phraseological component of a language depending on characteristics of phraseologisms and methods of their study.

Unfortunately, in English and American linguistic literature there is little works, especially devoted to the theories of phraseology, but also in available significant works ( A. Makkey, U. Veynreyh, L. P. Smith) are not put such fundamental questions as scientifically motivated criteria of the separation of phraseologisms, correlation of phraseological units with words, systematicity of phraseology, phraseological variantiveness, phrase formation, method of study of phraseology and others.

Functionally and semantically inseparable units are usualᄀly called phraseological units. Phraseological units cannot be freely made up in speech but are reproduced as ready made units. The lexical components in phraseological units are stabᄀle and they are non-motivated i. e. its meaning cannot be deduced from the meaning of its components and they do not allow their lexical components to be changed or substituted.

In phraseological units the individual components do not seem to possess any lexical meaning outside the word group.

For example: red tape (bureaucratic methods), to get rid of; to take place; to lead the dance; to take care.

Prof. A. I. Smirnitsky states that a phraseological unit may be defined as specific word groups functioning as a word-equi-vvalent. The phraseological units are single semantically inse $\neg$ parable units. They are used in one function in the sentence and belong to one part of speech [2].

Academician V. V. Vinogradov spoke of the semantic change in phraseological units as "a meaning resulting from a peculiar chemical combination of words". This seems a very apt comparison because in both cases between which the parallel is drawn an entirely new quality comes into existence.

The semantic shift affecting phraseological units does not consist in a mere change of meanings of each separate constituent part of the unit. The meanings of the constituents merge to produce an entirely new 
CURRENT RESEARCH JOURNAL OF PHILOLOGICAL SCIENCES

(ISSN -2767-3758)

VOLUME 03 ISSUE 01 Pages: 127-131

SJIF IMPACT FACTOR (2021: 5. 823)

OCLC - 1242423883 METADATA IF - 6.925

Crossref

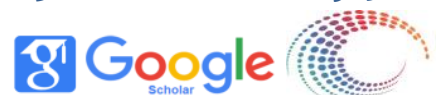

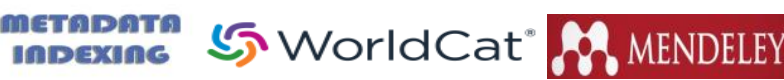

Publisher: Master Journals

meaning: e. g. to have a bee in one's bonnet means "to have an obsession about something; to be eccentric or even a little mad". The humorous metaphoric comparison with a person who is distracted by a bee continually buzzing under his cap has become erased and half-forgotten, and the speakers using the expression hardly think of bees or bonnets but accept it in its transferred sense: "obsessed, eccentric". Phraseological units are characterised by semantic unity. In the traditional approach, phraseological units have been defined as word-groups conveying a single concept (whereas in free word-groups each meaningful component stands for a separate concept).

It is this feature that makes phraseological units similar to words: both words and phraseological units possess semantic unity (see Introduction). Yet, words are also characterised by structural unity which phraseological units very obviously lack being combinations of words.

Most Russian scholars today accept the semantic criterion of distinguishing phraseological units from free word-groups as the major one and base their research work in the field of phraseology on the definition of a phraseological unit offered by Professor A. V. Koonin, the leading authority on problems of English phraseology in our country:

"A phraseological unit is a stable word-group characterised by a completely or partially transferred meaning".

The second type is represented by phraseological units in which one of the components preserves its current meaning and the other is used in a transferred meaning: to lose (keep) one's temper, to fly into a temper, to fall ill, to fall in love (out of love), to stick to one's word (promise), to arrive at a conclusion, bosom friends, shop talk (also: to talk shop), small talk.
Here, though, we are on dangerous ground because the border-line dividing phraseological units with partially changed meanings from the so-called semifixed or non-phraseological word-groups (marginal cases) is uncertain and confusing.

The term "idiom", both in this country and abroad, is mostly applied to phraseological units with completely transferred meanings, that is, to the ones in which the meaning of the whole unit does not correspond to the current meanings of the components. There are many scholars who regard idioms as the essence of phraseology and the major focus of interest in phraseology research.

The structural criterion also brings forth pronounced distinctive features characterising phraseological units and contrasting them to free word-groups.

Structural invariability is an essential feature of phraseological units, though, as we shall see, some of them possess it to a lesser degree than others. Structural invariability of phraseological units finds expression in a number of restrictions.

First of all, restriction in substitution. As a rule, no word can be substituted for any meaningful component of a phraseological unit without destroying its sense. To carry coals to Manchester makes as little sense as B Харьков со своим самоваром.

The idiom to give somebody the cold shoulder means "to treat somebody coldly, to ignore or cut him", but a warm shoulder or a cold elbow make no sense at all. The meaning of a bee in smb's bonnet was explained above, but a bee in his hat or cap would sound a silly error in choice of words, one of those absurd slips that people are apt to make when speaking a foreign language. 
CURRENT RESEARCH JOURNAL OF PHILOLOGICAL SCIENCES

(ISSN -2767-3758)

VOLUME 03 ISSUE 01 Pages: 127-131

SJIF IMPACT FACTOR (2021: 5. 823)

OCLC - 1242423883 METADATA IF - 6.925

\section{Crossref do
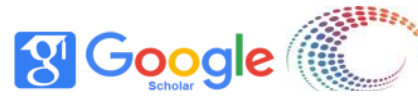

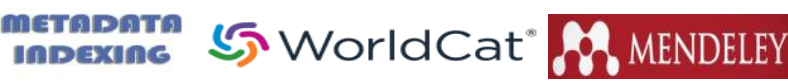

Publisher: Master Journals

In the phraseological unit to carry coals to Newcastle no additional components can be introduced. Nor can one speak about the big white elephant (when using the white elephant in its phraseological sense) or about somebody having his heart in his brown boots.

The third type of structural restrictions in phraseological units is grammatical invariability. A typical mistake with students of English is to use the plural form of fault in the phraseological unit to find fault with somebody (e. g. The teacher always found faults with the boy). Though the plural form in this context is logically well-founded, it is a mistake in terms of the grammatical invariability of phraseological units. A similar typical mistake often occurs in the unit from head to foot (e. g. From head to foot he was immaculately dressed). Students are apt to use the plural form of foot in this phrase thus erring once more against the rigidity of structure which is so characteristic of phraseological units.

\section{CONCLUSION}

To summarize, phraseological units are characterized by semantic unity. In the traditional approach, phraseological units have been defined as wordgroups conveying a single concept (whereas in free word-groups each meaningful component stands for a separate concept).

\section{REFERENCES}

1. Виноградов В.В. Об основных типах фразеологических единиц в русском языке // Виноградов В.В. Лексикология и лексикография: Избр. Тр. - М.: Наука, 1986. 125 стр.

2. Смирницкий А.И. Лексикология английского языка. - М., 1996. 78 стр.
3. Anderson, James M. (2006). Malmkjær, Kirsten (ed.). The Linguistics encyclopedia(Ebook ed.). London: Routledge. p. 601. ISBN 0-203-43286-X

4. McDonald, L. J. (2005). The meaning of e- : neologisms as markers of culture and technology.

5. Forgue, Guy (1979). "American Neologisms as a Reflection of Cultural Change since 1945". Proceedings of a Symposium on American Literature: 199-211. 